\title{
Evaluation of Systemic Steroid Response Via Digital Infrared Thermal Imaging (DITI) in Patients with Idiopathic Granulomatous Mastitis
}

\section{Idiyopatik Granülomatöz Mastitli Hastalarda Dijital Kizilötesi Termal Görüntüleme (DiTi) ile Sistemik Steroid Yanitinin Değerlendirilmesi}

\author{
Murat Sendur ${ }^{1} \oplus$, Engin Hatipoglu ${ }^{2} \oplus$, Varol Celik ${ }^{2} \odot$ \\ ${ }^{1}$ Department of General Surgery, Istanbul Bahcelievler State Hospital, Istanbul, Turkey \\ ${ }^{2}$ Department of General Surgery, Istanbul University, Cerrahpasa Medical School, Istanbul, Turkey
}

Received: 07.05.2020 / Accepted: 13.07.2020 / Published Online: 30.09.2020

Cite as: Sendur M, Hatipoğlu E, Celik V. Evaluation of systemic steroid response via digital Infrared Thermal Imaging (DITI) in patients with idiopathic granulomatous mastitis. Med J Bakirkoy 2020;16(3):218-23.

\section{ABSTRACT}

Objective: The aim of this study is to evaluate the pre-treatment and post-treatment thermography images of patients who received steroid treatment with a diagnosis of granulomatous mastitis, and to determine whether the thermography device is an effective imaging method in the follow-up.

Method: This retrospective study was conducted by the Breast Surgery Working Group of Cerrahpaşa Medical Faculty, Department of General Surgery. Fifteen patients who applied to the center between January 1, 2013 and May 31, 2015, and received steroid treatment due to granulomatous mastitis were included in the study. Digital Infrared Thermal Imaging (DITI) results at the beginning and end of the treatment were compared.

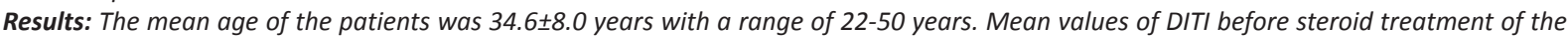
inflamed area was $34.3 \pm 0.7^{\circ} \mathrm{C}$ which was significantly higher than the post-treatment mean DITI $\left(31.1 \pm 1.1^{\circ} \mathrm{C}\right)$. The mean pre-treatment, and post-treatment DITI values recorded in healthy breasts were $30.1 \pm 1.3^{\circ} \mathrm{C}$ and $29.6 \pm 1.1^{\circ} \mathrm{C}$, respectively. The DITI values of patients with granulomatous mastitis were significantly higher than the results of the healthy group, both before and after treatment. In the pre-treatment DITI measurements, the thermographic image demonstrated a discerning septal image which was considered to show the region where inflammation was severe. The appearance of this 'serpentine' image, which was detected in 8 patients before the treatment, disappeared as a result of treatment.

Conclusion: Systemic steroid treatment is an effective option in the treatment of patients with granulomatous mastitis, and our results have shown that DITI can be used in the follow-up of response to treatment.

Keywords: Granulomatous mastitis, systemic steroid treatment, response to treatment, digital infrared tranformation inductor

öz

Amaç: Bu çalışmanın amacı, granülomatöz mastit tanısı ile steroid tedavisi alan hastaların tedavi öncesi ve tedavi sonrası infrared termografi görüntülerinin değerlendirilmesi ve infrared termografi cihazının takipte etkili bir görüntüleme yöntemi olup olmadığını belirlemektir. Yöntem: Bu retrospektif kohort çalışması Cerrahpaşa Tıp Fakültesi Meme Cerrahisi Çalışma Grubu tarafından gerçekleştirildi. 1 Ocak 2013 ile 31 Mayıs 2015 tarihleri arasında merkeze başvuran ve granülomatöz mastit nedeniyle steroid tedavisi alan 15 hasta çalışmaya dahil edildi. Tedavinin başlangıcında ve sonunda dijital Infrared Termal Görüntüleme (DITI) sonuçları karşılaştırıldı.

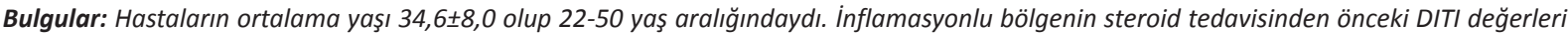
$\left(34,3 \pm 0,7^{\circ} \mathrm{C}\right)$, tedavi sonrası ortalamadan $\left(31,1 \pm 1,1^{\circ} \mathrm{C}\right)$ istatistiksel olarak anlamlı ölçüde yüksekti. Sağlıklı memelerde kaydedilen ortalama tedavi öncesi DITI ölçümü tekrar ölçümde $30,1 \pm 1,3^{\circ} \mathrm{C}$ ve $29,6 \pm 1,1^{\circ} \mathrm{C}$ idi. Granülomatöz mastitli hastaların DITI sonuçları, tedaviden önce ve sonra sağlıklı grubun sonuçlarından anlamlı derecede yüksekti. Tedavi öncesi DITI ölçümlerinde, termografik görüntü, inflamasyonun șiddetli olduğu bölgeyi gösterdiği düşünülen ayırt edici bir septal görüntü gösterdi. Tedaviden önce 8 hastada saptanan bu "serpantin" görüntüsünün görünümü, tedavi sonucunda ortadan kayboldu.

Sonuç: Granülomatöz mastitli hastaların tedavisinde sistemik steroid tedavisi etkili bir seçenektir, sonuçlarımız DITI'nin tedaviye yanıt takibinde kullanılabileceğini göstermektedir.

Anahtar kelimeler: Granülomatöz mastit, sistemik steroid tedavisi, tedaviye yanıt, dijital kızılötesi transformasyon indüktörü

Corresponding Author:

enginhatipoglu@yahoo.com
M. Sendur 0000-0002-5945-6374

E. Hatipoğlu 0000-0002-5536-3808
V. Celik 0000-0001-6228-2443 


\section{INTRODUCTION}

Idiopathic Granulomatous Mastitis (IGM), a disease that is easily confused with breast cancer both clinically and radiologically, is classified as a non-infectious condition with unknown etiology without any specific treatment. Granulomatous inflammation is a special chronic inflammation that occurs when activated macrophages aggregate. After excluding other factors that cause granuloma in the breast, the diagnosis of IGM can be made. However, definitive diagnosis can be made by histopathological examination of affected breast tissue ${ }^{(1)}$.

Infrared radiation detected by more advanced systems can be converted into formats that can be visualized -and more importantly- quantified and monitored. Digital Infrared Thermal Imaging (DITI) is an imaging method that has been developed for this purpose. It has found clinical use as a modality that can measure the increase in temperature caused by inflammation on the body surface ${ }^{(2)}$. DITI is a prime example of a noninvasive, simple and safe diagnostic technique. Lack of contact, pain (such as in mammography) or radiation exposure (such as in X-ray or tomography), are also considered to be important components of comfortable diagnostic methods for patients ${ }^{(3,4)}$. Despite the use of various successful methods for diagnosis and their discerning advantages over each other, several studies have suggested that thermographic imaging may be utilized to determine the size and aggressiveness of tumors (5-7). Studies investigating mastitis with thermal images were carried out only in veterinary studies on animals and this method was shown to be effective ${ }^{(8)}$.

The optimal option in the treatment of IGM is not clear. Depending on the condition of the symptoms, use of steroids up to 3 to 6 months and surgery may be required in cases not responding to initial treatments ${ }^{(9)}$. To our knowledge, there is no study in which DITI was used in the diagnosis or treatment follow-up of IGM. For this reason, the aim of this study was to investigate the pre-treatment and posttreatment DITI results of patients who were recipients of steroid treatment with a diagnosis IGM, and to determine whether the DITI could prove to be an effective imaging method in the evaluation of treatment response.

\section{MATERIAL AND METHOD}

This study was carried out between January 1, 2013 and May 31, 2015 by a commission formed by infectious disease specialists and members of the Breast Surgery Working Group of Cerrahpaşa Medical Faculty. Patients who received steroid treatment due to IGM were prospectively included in the study. Evaluation of patients were performed with DITI imaging before and after treatment at the Radiology Department of Cerrahpaşa Medical Faculty. Ethics committee approval was obtained from the Ethics Committee of Cerrahpaşa Medical Faculty at the beginning of the study (Date: 04/10/2015, Approval number: 83045809/604.01/02-109/20). Informed consent was obtained from all individual participants included in the study. All examination, diagnosis, treatment and follow-up stages of the patients were carried out by the Cerrahpaşa Medical Faculty General Surgery Department Breast Surgery Working Group.

\section{Patient selection}

The files of patients who applied to the departments Cerrahpaşa Medical Faculty of General Surgery and Infectious Diseases with mastitis findings and were determined to not have simple mastitis were examined and screened. Fifteen patients who were followed with a preliminary diagnosis of IGM and diagnosed with unilateral IGM after biopsy were included in the study.

\section{Treatment and follow-up}

Methyl-prednisolone treatment was prescribed at a dose of $0.5 \mathrm{mg} / \mathrm{kg} /$ day and thermography images were taken with the DITI device in the Cerrahpaşa Medical Faculty Radiology Department Breast Imaging Unit before starting treatment. The patients were followed at the weekly Mastitis Meeting organized jointly by Infectious Diseases and General Surgery Departments. Methylprednisolone treatment of patients who showed clinical improvement was tapered and discontinued and thermographic imaging was performed with DITI device approximately 1 month later.

\section{DITI procedure}

In our study, Meditherm med $2000^{\circ}$ device was used for digital infrared imaging. During the shooting, the temperature of the room was kept at an average of 
$18-22^{\circ} \mathrm{C}$. Patients were kept in the pre-cooled room for 5 minutes, with the waist up naked. The patient's hands were joined at the nape, and 8 images were taken for each patient from anterior, posterior, right axilla, left axilla, right oblique and left oblique views (Figure 1). The whole procedure took an average of 12 minutes.

Using the Wintes Thermal Evaluation Software (version 1.05.0005), measurements were made by scanning the areas affected by granulomatous mastitis and healthy breasts.

\section{Statistical Analysis}

Mean, standard deviation, median, lowest, highest, frequency and ratio values were used in the descriptive statistics of the data. The distribution of continuous variables was checked by the KolmogorovSmirnov test. The Wilcoxon Signed-Rank Test and the McNemar test were used in the analysis of repeated measurements. The SPSS v22.0 program was used for the conduct of all statistical analyses.

\section{RESULTS}

The mean age of the patients was $34.6 \pm 8.0$ with a range of 22-50 years. The mean DITI measurements of the diseased breast before methyl-prednisolone treatment was $34.3 \pm 0.7^{\circ} \mathrm{C}$. One month after the treatment (post-treatment measurement) this value was $31.1 \pm 1.1^{\circ} \mathrm{C}$. Compared with pretreatment values, there was a statistically significant decrease in temperature after treatment $(p<0.05)$. Measurements were also made on the healthy contralateral breast for comparison. While the mean DITI measurements in healthy breasts before, and after treatment were
Table 1. DITI results before and after steroid treatment.

\begin{tabular}{lccc}
\hline & $\begin{array}{c}\text { Breast with IGM } \\
(\mathbf{n}=\mathbf{1 5})\end{array}$ & $\begin{array}{c}\text { Healthy breast } \\
(\mathbf{n}=\mathbf{1 5})\end{array}$ & $\mathbf{p}$ \\
& & & \\
\hline Before treatment $\left({ }^{\circ} \mathrm{C}\right)$ & $34.3(33-36)$ & $30.1(28-33)$ & $<0.001$ \\
After treatment $\left({ }^{\circ} \mathrm{C}\right)$ & $31.2(30-33)$ & $29.9(28-31)$ & $<0.001$ \\
$P$ & $<0.001$ & 0.207 & \\
\hline
\end{tabular}

Data are given as median (minimum - maximum)

$30.1 \pm 1.3^{\circ} \mathrm{C}$, and $29.6 \pm 1.1^{\circ} \mathrm{C}$, respectively. There was no significant difference between DITI measurements in healthy breasts before and after treatment $(p>0.05)$. In both the pre-treatment and posttreatment period, DITI results of healthy breasts were significantly lower compared to breasts with IGM ( $\mathrm{p}<0.05$, Table 1).

We detected that patients who had active IGM showed a septal image in the thermography shots of the abscess area. This image, which was defined as a serpentine by radiologists, was detected more prominently in patients who were in the active stage of the disease. This finding was detected in 8 of the 15 patients, but it regressed completely in 7 patients after treatment ( $p<0.05$, Figure 2, Table 2$)$.

Table 2. Serpentine detection in DITI before and after steroid treatment.

\begin{tabular}{lccc}
\hline & $\begin{array}{c}\text { Serpentine } \\
\text { before treatment } \\
(\mathbf{n}=\mathbf{8})\end{array}$ & $\begin{array}{c}\text { No Serpentine } \\
\text { before treatment } \\
(\mathbf{n}=\mathbf{8})\end{array}$ & $\mathbf{p}$ \\
\hline $\begin{array}{l}\text { Serpentine after } \\
\text { treatment }\end{array}$ & $1(12.5 \%)$ & - & 0.016 \\
$\begin{array}{l}\text { No Serpentine after } \\
\text { treatment }\end{array}$ & $7(87.5 \%)$ & $7(100.0 \%)$ & \\
\hline
\end{tabular}

Data are given as frequency (percentage of column)

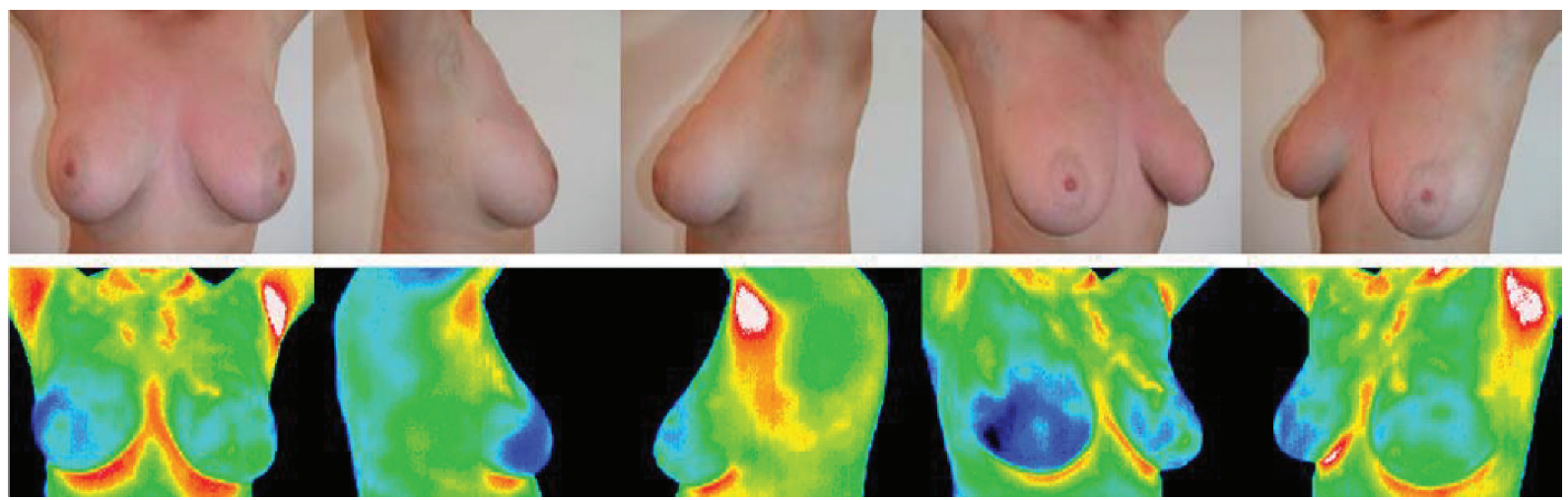

Figure 1. Shooting positions and thermographic provisions. 

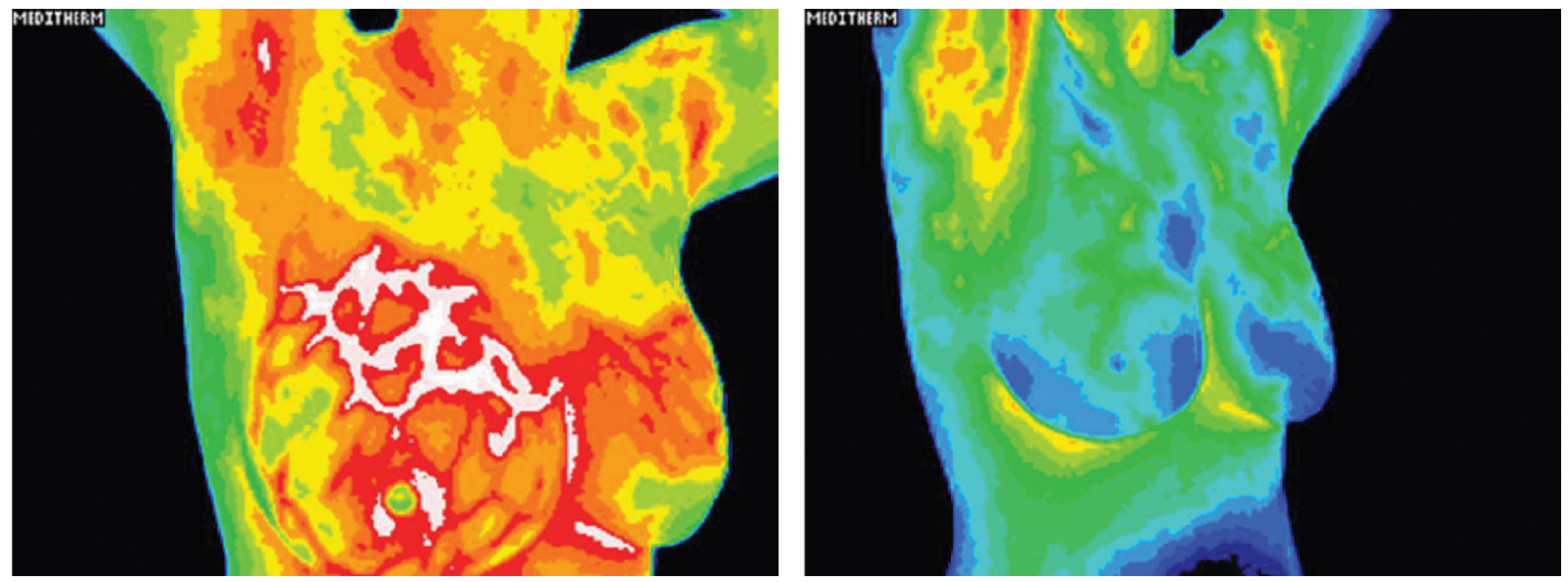

Figure 2. DITI image of the septal image we call serpentine in granulomatous mastitis (left) and healed after treatment (right).

\section{DISCUSSION}

In our study, it was determined that the increase in temperature due to inflammation in IGM can be detected with DITI. According to our results, it can be said that steroid is an effective option in IGM treatment and DITI is a successful imaging method in the treatment follow-up. However, it is also important to mention that other treatment approaches do exist. For instance, in their examination of 81 IGM patients, Aydın et al., reported that those who received antibiotics had shorter recovery time compared to people undergoing the standard immunosuppressive or surgical treatment -given that lesion size was 2 $\mathrm{cm}$ or smaller ${ }^{(10)}$. In our study, other treatment modalities were not examined. In future studies, better interpretations can be made by examining these features and comparing their results, especially with regard to DITI evaluation.

In the literature, no study has been encountered that performed the diagnosis and follow-up of IGM with DITI. In their reviews evaluating the imaging methods used in IGM, Hasbahceci and Kadioglu, reported that 30 studies published on this subject used ultrasonography (USG), mammography and magnetic resonance imaging (MRI) ${ }^{(11)}$. In a similar study, Fazzio et al. reported that the most ideal method for clinical follow-up of patients diagnosed with IGM was MRI, and that any infrared imaging method was not preferred in any patient ${ }^{(12)}$. Kocaoğlu et al. ${ }^{(13)}$ reported that MRI was superior in comparison to USG in the diagnosis of IGM and biopsy is still required for the definitive diagnosis, but they did not mention the DITI method. Different studies have also examined the methods used in the diagnosis of IGM, but DITI has not been mentioned ${ }^{(14)}$. As far as our detailed literature review has revealed, this study is the first study in which steroid treatment follow-up in IGM was evaluated with DITI results. Although we could not compare with other methods and other lesions in our study, it was determined that DITI was an effective method in the follow-up of IGM treatment with systemic steroids. Although thermal images are not preferred in mastitis cases in humans, they are especially useful in terms of breast health of animals that are important in the dairy industry; Thermal images are widely used in screening, diagnosis, follow-up and treatment response. Many animal studies have evaluated the results of diagnosis and follow-up of the cases with mastitis with infrared thermal images. As a result of these studies, thermal imaging method has been shown to be effective ${ }^{(15-17)}$.

Studies conducted in other parts of the body have reported that the infection / inflammation in any region can be detected by thermography, and the patient's well-being can be confirmed by the improvement of this abnormality. Among these studies, Kawali reported that the inflammatory or noninflammatory state of ocular lesions can be detected by thermal imaging ${ }^{(18)}$. Denoable et al. ${ }^{(19)}$ found that patellar thermal imaging results reflect the severity of osteoarthritis and that the regression or progression of the disease can be monitored with this method. In a study conducted by Saxena and Willital, the importance of thermography in determining skin 
and extremity infections was demonstrated (20). In addition, there are different studies in which inflammation and the results of treatment in different diseases were monitored by thermal imaging ${ }^{(21-23)}$. In our study, it was shown that DITI results provide information about progression and recovery in IGM, where the inflammation process is quite active. Considering the results of other studies, it seems that DITI is an advantageous option in the evaluation of inflammatory processes that are not only found in the breast area, but also in other parts of the body, especially when they are difficult to diagnose and treat with other methods.

IGM is a rare condition in which it is difficult to differentiate between infectious mastitis and breast carcinoma. The diagnosis is made by exclusion of other possible diagnoses and imaging methods facilitate this process ${ }^{(12)}$. It has been observed that studies examining the thermographic imaging of breast tissue are mostly performed for the diagnosis, treatment and prognosis of breast cancer (24). IGM symptoms and imaging results are similar to those of malignant lesions. Therefore, this differential diagnosis is very important ${ }^{(25,26)}$. There are also studies in other diseases that have reported that distinction with DITI is inadequate ${ }^{(27)}$. Sarıgöz et al. examined the diagnostic reliability of DITI in 54 patients with palpable breast masses. They found that DITI had $95 \%$ sensitivity and $73 \%$ specificity in the distinction of malign-benign lesions. They reported that the highest temperatures were detected in IGM cases $\left(36 \pm 1^{\circ} \mathrm{C}\right)$ which were comparable to those seen in cases of invasive ductal carcinoma $(35 \pm 1)$. Therefore it was difficult to differentiate these two lesions with DITI. They also stated that both lesions have higher temperature than fibroadenoma, due to the presence of inflammation.

Breast temperature can be influenced by various features such as metabolic status of the body, blood supply of the breast, size and volume of the breast, breast adipose tissue and activity of the glands ${ }^{(28)}$. It has been reported that breast temperature may also change according to race, because several skin and adipose tissue-related characteristics are different among races ${ }^{(29)}$. In our study, these features that may affect DITI results have not been evaluated. Since our study is a single-center study, its generali- zability is also limited. It is also evident that the reliability of the presented results were as much as those reported by healthcare professionals who performed and interpreted imaging results. It is also important to remember that while other methods have years and years of experience in imaging studies and their limitations are well known, thermography does not have these advantages. Finally, in our study, other treatment modalities could not be examined. In future studies, better interpretations can be made by examining these features.

\section{CONCLUSION}

To our knowledge, this is the first study to examine the effectiveness of DITI in IGM treatment follow-up. We have also determined that response to treatment can be monitored by temperature changes in the inflamed area with DITI. In future, researches with greater number of patients, which comparatrively evaluated other imaging methods, and thermography results of other breast diseases will contribute to more effective management of IGM diagnosis and treatment.

Ethics Committee Approval: Approval was obtained from the Istanbul University Cerrahpaşa Medical Faculty Ethics Committee (10.04.2015 - 109120).

Conflict of Interest: The authors declare that there is no conflict of interest.

Funding: There is no funding received for the current study.

Informed Consent: All participants signed a informed consent.

\section{REFERENCES}

1. Altıntoprak F, Baytekin HF, Altınay AE, Eren T. Meme kanserini taklit eden idiyopatik granülomatöz mastit. Meme Sağlığı Dergisi. 2009;5(1):40-3. Available from: https://www.eurjbreasthealth.com/content/files/sayilar/14/buyuk/1491.pdf

2. Jones BF. A reappraisal of the use of infrared thermal image analysis in medicine. IEEE Trans Med Imaging. 1998;17(6): 1019-27. https://doi.org/10.1109/42.746635

3. Parisky YR, Sardi A, Hamm R, Hughes K, Esserman L, Rust S, et al. Efficacy of computerized infrared imaging analysis to evaluate mammographically suspicious lesions. AJR Am J Roentgenol. 2003;180(1):263-9. https://doi.org/10.2214/ajr.180.1.1800263

4. Jones BF, Plassmann P. Digital infrared thermal imaging of human skin. IEEE Eng Med Biol Mag. 2002;21(6):41-8. https://doi.org/10.1109/MEMB.2002.1175137

5. Wishart GC, Campisi M, Boswell M, Chapman D, Shackleton V, Iddles $S$, et al. The accuracy of digital infrared imaging for 
breast cancer detection in women undergoing breast biopsy. Eur J Surg Oncol. 2010;36(6):535-40. https://doi.org/10.1016/j.ejso.2010.04.003

6. Ng EY, Ung LN, Ng FC, Sim LS. Statistical analysis of healthy and malignant breast thermography. J Med Eng Technol. 2001;25(6):253-63. https://doi.org/10.1080/03091900110086642

7. Sterns EE, Zee B, SenGupta S, Saunders FW. Thermography. Its relation to pathologic characteristics, vascularity, proliferation rate, and survival of patients with invasive ductal carcinoma of the breast. Cancer. 1996;77(7):1324-8.

https://doi.org/10.1002/(SICI)1097-0142(19960401)77: 7<1324::AID-CNCR15>3.0.CO;2-3

8. Hovinen M, Siivonen J, Taponen S, Hanninen L, Pastell M, Aisla AM, et al. Detection of clinical mastitis with the help of a thermal camera. J Dairy Sci. 2008;91(12):4592-8. https://doi.org/10.3168/jds.2008-1218

9. Wolfrum A, Kummel S, Theuerkauf I, Pelz E, Reinisch M. Granulomatous mastitis: a therapeutic and diagnostic challenge. Breast Care (Basel). 2018;13(6):413-418. https://doi.org/10.1159/000495146

10. Aydın HO, Baykal A, Konan A, Kaynaroğlu V. Idiopathic granulomatous mastitis: factors influencing recovery and recurrence. The European Research Journal 2019;5(5):768-75. https://doi.org/10.18621/eurj.424016

11. Hasbahceci M, Kadioglu $\mathrm{H}$. Use of imaging for the diagnosis of idiopathic granulomatous mastitis: a clinician's perspective. J Coll Physicians Surg Pak. 2018;28(11):862-7. https://doi.org/10.29271/jcpsp.2018.11.862

12. Fazzio RT, Shah SS, Sandhu NP, Glazebrook KN. Idiopathic granulomatous mastitis: imaging update and review. Insights Imaging. 2016;7(4):531-9. https://doi.org/10.1007/s13244-016-0499-0

13. Kocaoglu M, Somuncu I, Ors F, Bulakbasi N, Tayfun C, Ilkbahar S. Imaging findings in idiopathic granulomatous mastitis. A review with emphasis on magnetic resonance imaging. J Comput Assist Tomogr. 2004;28(5):635-41. https://doi.org/10.1097/01.rct.0000131927.82761.40

14. Yildiz S, Aralasmak A, Kadioglu H, Toprak H, Yetis H, Gucin Z, et al. Radiologic findings of idiopathic granulomatous mastitis. Med Ultrason. 2015;17(1):39-44. https://doi.org/10.11152/mu.2013.2066.171.rfm

15. Ayadi M, Aljumaah RS, Samara EM, Alshaikh MA, Caja G. Use of infrared thermography for mastitis detection in lactating dairy camels (Camelus dromedarius). In: Proceedings of the International Camel Conference. Camel Publishing House; 2015. p. 55-60.

16. Colak A, Polat B, Okumus Z, Kaya M, Yanmaz LE, Hayirli A. Short communication: early detection of mastitis using infrared thermography in dairy cows. J Dairy Sci. 2008;91(11): 4244-8.

https://doi.org/10.3168/jds.2008-1258

17. Wollowski L, Bertulat S, Kossatz A, Heuwieser W. Short communication: Diagnosis and classification of clinical and subclinical mastitis utilizing a dynamometer and a handheld infrared thermometer. J Dairy Sci. 2019;102(7):6532-9. https://doi.org/10.3168/jds.2018-15509

18. Kawali AA. Thermography in ocular inflammation. Indian J Radiol Imaging 2013;23(3):281-3. PMID: 24347863.

19. Denoble AE, Hall N, Pieper CF, Kraus VB. Patellar skin surface temperature by thermography reflects knee osteoarthritis severity. Clin Med Insights Arthritis Musculoskelet Disord. 2010;3:69-75. https://doi.org/10.4137/CMAMD.S5916

20. Saxena AK, Willital GH. Infrared thermography: experience from a decade of pediatric imaging. Eur J Pediatr. 2008;167(7):757-64.

https://doi.org/10.1007/s00431-007-0583-z

21. Chanmugam A, Langemo D, Thomason K, Haan J, Altenburger EA, Tippett $A$, et al. Relative temperature maximum in wound infection and inflammation as compared with a control subject using long-wave infrared thermography. Adv Skin Wound Care. 2017;30(9):406-14. https://doi.org/10.1097/01.ASW.0000522161.13573.62

22. Toutouzas K, Benetos G, Drakopoulou M, Bounas P, Tsekoura $D$, Stathogiannis K, et al. Insights from a thermography-based method suggesting higher carotid inflammation in patients with diabetes mellitus and coronary artery disease. Diabetes Metab. 2014;40(6):431-8 https://doi.org/10.1016/j.diabet.2014.05.005

23. Castillo-Martinez C, Valdes-Rodriguez R, Kolosovas-Machuca ES, Moncada B, Gonzalez FJ. Use of digital infrared imaging in the assessment of childhood psoriasis. Skin Res Technol. 2013;19(1):e549-51. https://doi.org/10.1111/j.1600-0846.2011.00611.x

24. Shahari S, Wakankar A. Color analysis of thermograms for breast cancer detection. 2015 International Conference on Industrial Instrumentation and Control. 2015. p. 1577-81. https://doi.org/10.1109/IIC.2015.7151001

25. Prasad S, Jaiprakash P, Dave A, Pai D. Idiopathic granulomatous mastitis: An institutional experience. Turk J Surg. 2017;33(2):100-3. https://doi.org/10.5152/turkjsurg.2017.3439

26. Han B, Choe Y, Park J, Moon W, Ko YH, Yang J-H, et al. Granulomatous mastitis: Mammographic and sonographic appearances. AJR Am J Roentgenol. 1999;173(2):317-20. https://doi.org/10.2214/ajr.173.2.10430126

27. Sarigoz T, Ertan T, Topuz O, Sevim Y, Cihan Y. Role of digital infrared thermal imaging in the diagnosis of breast mass: $A$ pilot study: Diagnosis of breast mass by thermography. Infrared Physics \& Technology. 2018;91:214-9. https://doi.org/10.1016/j.infrared.2018.04.019

28. Zeng J, Lin L, Deng F. Infrared thermal imaging as a nonradiation method for detecting thermal expression characteristics in normal female breasts in China. Infrared Physics \& Technology. 2020;104:103125. https://doi.org/10.1016/j.infrared.2019.103125

29. Habel LA, Capra AM, Oestreicher N, Greendale GA, Cauley JA, Bromberger J, et al. Mammographic density in a multiethnic cohort. Menopause. 2007;14(5):891-9. https://doi.org/10.1097/gme.0b013e318032569c 